\title{
Totning med hale
}

\author{
I mellomkrigstiden var det stor interesse for det paranormale. Fenomenet er infamt skildret i danske Hans \\ Scherfigs /dealister. I Norge var spritisme et element i den berømte Køber-saken, der datteren til byfogd Dahl \\ i Fredrikstad (som ble funnet druknet på Hankø) ble anklaget for å ha drept ham. Men at poltergeister skulle \\ finne veien inn på sykehuset på trauste Toten, er virkelig egnet til å forbause. I Tidsskriftet nr. 20/1934 anmodet \\ redaktør Schiøtz doktor Schjønsby om en oppklaring, og i Tidsskriftet nr. 23/1934 kommer den. Det er da \\ redaktøren ikke kan dy seg (Tidsskr Nor Lægeforen 1934; 54: 1238-40).
}

Innhold.

Originalartikler: C-vitaminet i norske bær og bærkonserver. Av Ottar Rygh, Ragna Knudsen og Haakon Natvig, Oslo. S. 1033. - Lægetilsyn $i$ internater $i$ Oslo. Av sundhetsinspektør Alfred Sundal, Oslo. S. 1044. - Borddansen på Toten. Av Carl Schiøtz. S. 1056.

\section{Innhold.}

Originalartikler: Om simple anemier og deres behandling. Av $R$. Hatlehol, Oslo. S. 1221. - Poliomyelitt i Andenes. Av Johs. Hagtvet, Andenes i Vesterålen. S. 1231. - Fenomenene på Toten. S. 1238.

\section{Fenomenene på Toten}

Hr. professor C. Schiøtz.

Som svar på deres henvendelse i nr. 20 tør jeg med en gang forsikre at jeg ikke har truffet et eneste menneske her som har satt de «skøieraktige» eller «hysteriske» småjenter i forbindelse med byfoged Dahls død eller den av Dem ilde omtalte «psykiske» forskning. Det kunde være av interesse å få litt beskjed om hvad slags «fyrer» som driver den slags forskning. - Kan de ikke få en eller annen som vet litt om «psykisk forskning», til å fortelle?

Om borddansen har jeg svært lite å berette: Efter at jeg omsider hadde fått høre om nattbordet og andre gjenstander som rørte sig, var det om å gjøre å få se nattbordet i funksjon. Mandag a f te n d e n 24. s e p t e m be r k1. 20.30 befant jeg mig derfor på de to's sykestue sammen med en kollega og to sykepleiersker. For sikkerhets skyld lanserte jeg på forhånd teorien om «skøierstreker». Søster hadde ikke vært mindre skarpsindig; også hun hadde vært inne i samme originale tankerekke; hun hadde til og med vært riktig streng og sagt fra, at noget slikt tull fikk de værsågod holde op med. Hun slukket lyset og dermed sov de to. Imidlertid skulde vi ikke slippe så lett. Flere «lettroende» individer av høist forskjellig livsstilling, innstilling, livsopfatning og politisk overbevisning, berettet nemlig pussige ting om nattbordenes forbausende mobilitet. Småjentene var nok ikke redde lenger; jeg hadde forklart dem, at slikt småtteri hadde ikke noget å bety, det vilde snart gi sig, og jeg trodde, sa jeg, at den slags hadde hendt før i forbindelse med syke barn. Dette skulde være «veiledning» forstås ; men ak, også her var søster Astrid kommet mig i forkjøpet ; altså kl. $20.30 \mathrm{fiksertes} \mathrm{de} \mathrm{to} \mathrm{småjenter} \mathrm{forsvarlig,} \mathrm{lyset} \mathrm{blev}$ slukket, for det blev fremholdt at det lettere hender noget i mørke. Næsten med én gang flyttet det ene bord sig, riktignok en ringe flytning, men tydelig. Dette er det eneste jeg har hørt og sett og som jeg kan gå god for.

Jeg kan nemlig ikke forstå at der fantes den ringeste mulighet for nogen av de tilstedeværende å nå det bord.

Omtrent det samme fremholdes av andre som tilfeldigvis har sett «fenomenene». Jeg henstillet inntrengende til alle de pressens menn som ustanselig telefonerte eller besøkte mig, ikke å lage sensasjon, fenomenene var lite fremtredende sa jeg, og jeg visste ikke bedre enn at de var mindre betydningsfulle. - De er for lengst ophørt, og jeg vil tilføie, at her på Toten (Østre Toten lægedistrikt) har ikke folk vært synderlig optatt av disse hendelser, simpelt hen av den gode grunn at rasen her ikke har slik innstilling. Interessene har i høst høist naturlig konsentrert sig om de fine avlinger og det sørgelige innhøstningsvær. (Sund mentalitet.)

Nogen bekymring for totningene er derfor helt overflødig. Jeg kjenner dem godt, ingen har tatt skade av disse «skøiersteker».

- Livet lever videre!

Lena 26. oktober 1934.

H. Schjønsby

Fra redaksjonen.

Prinsipielt er jeg imot at avis- og tidsskriftredaksjoner ved hjelp av såkalte «haler» forsøker å gjøre det av med forfatteres innlegg, og disse mine bemerkninger er langt fra tenkt å skulle gå i sådan retning.

Jeg takker herr Schjønsby for meddelelsen, det er i alles interesse at vi drøfter saken nærmere. Altså:

Mandag 24. september var doktor Schjønsby med en kollega og to sykepleiersker til stede i sykeværelset. Der står at søster slokket lyset og dermed «sov de to». Her må jeg spørre: Hvordan kan man vite at de sov i det øieblikk det var mørkt? Herom vet man efter min mening absolutt ingen ting. Fikseringens art bør også oplyses, likeså hvor langt omtrent bordet blev konstatert flyttet.

Det fremgår altså at denne kveld danner det eneste materiale sykehusets læge personlig har for hånden.

Som alle vet har avisene laget et stort nummer av fenomenene på Toten, og en kvinnelig representant for den «psykiske forskning» har skrevet en alvorlig artikkel i dagspressen nettop da diskusjonen om byfoged Dahls død var mest aktuell.

I dagspressen stod også omtalt forskjellige fenomener med vannglass som blev angitt å ha beveget sig gjennem rummet, slik at man gjentagne ganger måtte bytte tørt på en av de små patienter, altså samme rum. Dagspressen meddeler at det fulle vannglass tømte sig i hennes seng.

Redaksjonen vil være takknemlig for en meddelelse også om disse ting. Selvsagt er man opmerksom på at avisreferater ikke er egnet grunnlag for faglig diskusjon som regel. Avisene gav imidlertid inntrykk av at pleierskene var meget optatt av fenomenene, f. eks. med vannglassene. Det er ikke upåkrevet at redaksjonen får en meddelelse også herom.

Etter det som hittil foreligger, må jeg som en personlig bemerkning fremheve at det hele ennu står for mig som hysteri eller skøierstreker.

Carl Schiøtz. 